\title{
The Modern Reform of Arabic Learning Paradigm and Its' Contribution toward the Development of Islamic Studies
}

\author{
Heni Verawati (Corresponding Author) \\ heniverawati@radenintan.ac.id \\ Islamic State University of Raden Intan Lampung, Indonesia \\ Uswatun Hasanah \\ uswatunh@radenintan.ac.id \\ Islamic State University of Raden Intan Lampung, Indonesia
}

\begin{abstract}
Arabic learning is positively associated with the growth of Islamic studies. The better comprehension and mastery of Arabic, the faster and the greater the standard of Islamic studies would be. It can also be considered an effort to avoid any misconceptions or misinterpretations in understanding Islam's primary sources (Quran and Hadits) written in Arabic. Therefore, there is a need for more in-depth and continuous study to develop effective Arabic language learning, especially in a modern context. This paper aims to examine some of the previous discussions and research on reforming Arabic language learning to develop Islamic studies in a modern context. Arabic learners today are different from learners in the past who focus more on routine activities by relying on written sources. In this modern era, learners have complete access and freedom to determine the direction of learning they want and need for themselves. Moreover, the main priority in improving Arabic learning quality is by optimizing modern media and technology. Therefore, Arabic language experts need to partner and synergize with competent human resources to develop modern Arabic education and learning technology to produce a better education system in Arabic Learning and support Islamic Studies' development.
\end{abstract}

Keywords: modern reform; Arabic learning; Islamic studies

\section{A. INTRODUCTION}

Arabic has an excellent position for a Muslim's life, both in academic and spiritual life. Arabic as the primary language in studying Islam from its main source, Al Qur'an Hadith, is not only used for worship rituals but is also used to study various kinds of Islamic knowledge and literature as a fundamental source of higher scientific development. Moreover, the absoluteness of Arabic as the language of the Qur'an makes it an absolute and immutable language in the whole Muslims' life (Asy'ari, 2016). 
Learning Arabic also helps a person to have a better understanding and internalizing the teachings of Islam well since it can be cited and understood directly from the sources, which are the Al-Qur'an and the Sunnah, and avoid any misconceptions or misinterpretations in the understanding of these sources (Husen, 2016; Miftah W., 2017; Satrio, 2018). Understanding these primary sources of Islam requires a sufficiently high mastery of Arabic, leading to a need for the ongoing study of Arabic. Besides, Muslims' belief regarding Arabic as the God-language makes it more reasonable to be mastered by every Muslim (Satrio, 2018).

In recent developments, Arabic has finally got very significant attention from scientists and reviewers of Islamic studies in many fields. Many of these studies were related to the innovation of strategies in teaching Arabic in different contexts and language skills (W. Astuti, 2016; Baharudin, 2017; Fajriah, 2017; M. Khalilullah, 2011; Sangid \& Muhib, 2019); approaches or teaching designs (Muradi, 2014; Shodiq, 2018; Ummi \& Mulyaningsih, 2016); media (Azhari, 2015; Iswanto, 2017; Mahmudah, 2018); and some external influences in teaching and learning Arabic (Abdullah et al., 2015; Kassim et al., 2017; Wekke, 2016) which have been included as a part of formal and non-formal education curriculum. These institutions made a significant contribution to the development of Arabic language, which also impacted the rapid increase of the development of Islamic studies.

Arabic has two main uses simultaneously. The first is as a language of faith that is used in the process of worship and unifies the identity of Muslims around the world. The second is an international language of communication recognized by other nations, especially in the United Nations. This proves that mastery of the Arabic language is needed to achieve the target of happiness in the hereafter and as a key in living in the real world. Therefore, a Muslim should learn Arabic seriously and teach it to his family and surrounding communities to achieve success in the world and the hereafter (Wijaya, 2017).

Arabic is not a particular language only for Arabs or Muslims. Still, Arabic is the critical language in mastering Islamic sources and studying the entire history of Islamic development, which has dramatically influenced religious scholarship and general Islamic studies. Experts and researchers also consider Arabic to have high linguistic 
standards that open many opportunities to explore and analyze, especially on language elements. Therefore, studies and research in the Arabic language are still much needed (F. Astuti, 2016).

Learning Arabic and Islamic studies' development are closely related to one another and cannot be separated. Learning Arabic is a mandatory requirement in mastering the contents of the Qur'an and the Sunnah, which are also the primary sources in the development of Islamic studies. Furthermore, Arabic also has an essential role in international communication for both formal and non-formal forms in academic and non-academic life while also can be considered a means of communication as a human being towards the almighty god (Miftah W., 2017).

However, there are some misconceptions in society that learning Arabic can only be learned traditionally in Islamic boarding schools. Arabic learning in formal school is only limited to additional subjects that are not tested nationally. It does not affect the graduation and selection process of well-known universities. Thus, it then made the students' motivation and interest in learning Arabic very low (O. L. A. Wahab, 2013). Arabic learning has not yet got a special place in the general education curriculum in formal education which emphasizes more in general subjects while neglecting the optimization of religious learning, especially Arabic learning. Arabic is also considered inferior to other languages such as English, Mandarin, German and so on. This makes Arabic learning less developed informal educational (Azzuhri, 2009).

This condition is exacerbated by the government's policy, which is not very supportive of learning Arabic, both in the provision of Arabic language learning facilities and in increasing Arabic language skills for educators (Hizbullah \& Mardiah, 2015). This significantly impacts the development of learning methods and teaching systems that tend to be outdated in learning and teaching Arabic in formal schools. This problem also occurs in formal Islamic education institutions or madrasas which do not focus on the development of Arabic learning so that it ultimately disrupts and reduces the effectiveness of learning Islamic studies such as in understanding the Qur'an and hadith, Islamic law and Islamic history (Sagala, 2016; O. L. A. Wahab, 2013).

These problems also continue to rise with learners' difficulties in understanding every element of the Arabic language. The Arabic is quite complex in terms of lexis and 
meaning. In contrast to other languages such as English, which pays very significant attention to language learning, countries that use Arabic are less concerned with innovation and Arabic language learning variation. Besides, the less conducive environment for learning Arabic in formal schools also increase the problem of learning Arabic to another level (Azzuhri, 2009).

As there are many obstructions to learning Arabic in general, the development of communication and technology encourages the rapid development of Islamic studies followed by formal and non-formal Islamic institutions. However, this development of Islamic studies has not been supported by a significant development of Arabic language learning, resulting in a lack of basic understanding of critical Arabic terms as the key to understanding Islamic studies. With the demands of the increasing quality and quantity of Islamic studies, this provides a strong impetus for Islamic scholars to continue to improve and optimize efforts in Arabic learning innovation (Satrio, 2018).

Language studies, especially Arabic, have proven that language development would significantly affect knowledge, especially in Islamic studies. Islamic scholars must continue to increase their efforts to study Arabic more in-depth because these studies would greatly affect the Islamic religion's development. Literally and contextually, studying Arabic would be able to provide protection of various misconceptions in the interpretation of the Qur'an and the Sunnah that endanger the unity of Muslims and also reduce the potential for justifying the interests of another group's identity on the pretext of interpretation (Andriani, 2015).

In exploring and developing Islamic studies, detailed Arabic learning is needed, especially in developing vocabulary, syntax, semantics, and other Arabic elements, often leading to differences and multiple meanings. With the exploration and in-depth understanding of Arabic, it would prevent misconceptions and misinterpretations of every sentence or verse. It would be able to provide precise explanations to minimize the possibility of attempts to misuse the meaning of verses and hadiths taken for the benefit of a group (Humaidi, 2017).

From the overall explanation above, it can be concluded that learning Arabic has dramatically influenced the development of Islamic studies. Therefore, there is a need for more in-depth and continuous analysis to develop effective Arabic language 
learning, especially in the modern context. This paper aims to examine some of the previous discussions and research on reforming Arabic language learning to develop Islamic studies in a modern context.

\section{B. RESEARCH METHOD}

This research is library research using a descriptive approach. Library study is a research approach of collecting library data, reading and taking notes and processing research materials. Zed (2014) states that library research utilizes library sources in collecting research data without doing any field research. In library research, there are at least four main characteristics that the authors need to pay attention; those are researchers use knowledge from text or numerical data, not from what would happen in the field, researchers do not go directly to the field because researchers are dealing directly with existing data sources, library or online sources. In addition, researchers also collect and obtain second-hand data and not original data from the first data in the field (Supriyadi, 2017).

Several studies were selected as primary sources based on their direct connection toward the topic of this research, such as the development of Arabic and Islamic studies (Husen, 2016; Satrio, 2018; Wahyuni, 2017) and modern approach and strategies in Arabic teaching (Asy'ari, 2019; Setyawan \& Anwar, 2020; Wahab, 2015; Wijaya, 2017). At the same time, some studies were selected to support these ideas and other relevant information (W. Astuti, 2016; Azhari, 2015; Hizbullah \& Mardiah, 2015; Humaidi, 2017; Husen, 2016; Miftah W., 2017).

\section{FINDINGS AND DISCUSSION}

\section{The role of Arabic toward the Development of Islamic Studies}

As the advancement of technology and communication continues to rise, Islamic studies' development requires Islamic scholars and researchers to master the Arabic language because it would lead to the understanding and adequately interpreting AlQuran and hadiths. If Islamic scholars' Arabic language skills are low, this would disrupt Islamic scientific study, which comes from Arabic. Therefore, the most essential 
function of Arabic is not only as a means of daily communication between individuals but also as a scientific language that would determine the development of Islamic studies in the future (Satrio, 2018).

A better of understanding the Qur'an and its interpretation is also one of the main benefits in coordinating Arabic learning and Islamic learning, especially in understanding and memorizing important terms in religious rituals and also reducing the potential for misinterpretation, especially regarding ambiguous words and avoiding mistakes in providing meaning or interpretation. On the other hand, the development of Arabic language skills can also improve critical thinking ability in general and influence morals in daily life (Pane, 2018).

Learning Arabic can also be considered an essential key to exploring other religions, social, political, economic, and cultural (Andriani, 2015). Many phenomenal works of scholars in various fields are written in Arabic and require a more profound study to develop Islamic studies. Therefore it is significant for Muslims, mostly Muslim academics, to always improve their ability to master Arabic to establish Islamic studies as a whole.

There are at least four main reasons why Arabic is vital to be mastered by Muslim scholars concerning Islamic studies. First, the original and main sources of Islamic teachings, Al-Qur'an and hadith, were written in Arabic. Second, many of the books written by great scholars influence Muslims' development and thought in tafsir, hadith, fiqh, aqidah, and tasawuf and are registered in Arabic. Third, the source of Islamic religious studies would be more academic and have a better quality when taken from original references in Arabic. The fourth is that the lack of Islamic scholars who have high Arabic language skills. In this case, the development and implementation of Arabic learning are significant in producing religious expert. Another reason why Arabic is needed in Islamic studies is that Islamic institutions, especially Islamic universities, have received considerable attention from people who want to develop general abilities as well as religious understanding at the same time (Husen, 2016). Therefore, the optimization of Arabic learning would be able to help achieve these goals.

Good mastery of Arabic would also decrease the difficulties for a Muslim to study and produce Islamic studies. This mastery includes the ability to read, write and 
understand the everyday language used in Arabic. Also, the ability to speak Arabic would be able to help in memorizing the Qur'an and hadith more quickly and accurately as the primary sources of Islamic study. Learning Arabic also increases the motivation for learners to study Islamic studies independently based on each student's interests and abilities (Husen, 2016).

The development of general science, philosophy and medical science was translated into Arabic when the West (Europe) was experiencing a period of decline. At the same time, the eastern showed a glorious period in the Islamic world as the existence of the Koran and Hadith had become the focus of scientists' attention, so they are required to study and research developing science and technology. In this condition, Arabic becomes necessary because Arabic literature is studied in depth with the support of various Arabic knowledge types (Wahyuni, 2017).

In the historical view of the development of the Islamic religion in Indonesia, Arabic has become a critical role because it has become part of the subjects in informal, formal and non-formal forms of education. Arabic is not only one of the school subjects studied at Islamic educational institutions as Islamic boarding schools or in Islamic communities' daily activities, but Arabic has broadened outside the institution. At the same time, it also develops the national language of Indonesia, especially in the development of morphology, syntax, phonology and semantics. People's habits become affected by the urgency of the Arabic language in their lives. As a result of community interaction using Arabic, it was covered in some Indonesian terms (Wahyuni, 2017).

Overall, Arabic has an important role in fulfilling human life needs, especially Muslims in the fields of religion, science, technology, culture, and communication, which takes place between communities in the form of interaction in every community, including Muslims. Religious aspects are naturally related to scientific, cultural, and communication aspects (Wahyuni, 2017).

\section{Arabic Learning Expectation and Direction in the Modern Era}

The primary orientation in learning Arabic in the modern era is a communication approach assisted by learning media and modern technology. Arabic learners are expected to be able to communicate well in both formal and non-formal contexts as well as to produce scientific works that are useful in the development of Islamic studies and 
Arabic studies. As a means of communication, Arabic would also be significantly influenced by the development of modern technology. Therefore, Arabic learning must also be optimized with innovative technology-based learning methods that can provide more effective Arabic learning, increasing students' learning motivation (Wijaya, 2017).

Each field of study has a main orientation or purpose so that its implementation can be more focused and directed. In Arabic language learning, four main orientations should be promoted: (1) Religious Orientation, which is about learning Arabic to understand Islamic teachings (fahm al-maqru '). This orientation can be learning passive skills (listening and reading) and active skills (speaking and writing). (2) Academic orientation, which is about learning Arabic to understand Arabic language knowledge and skills (istima ', kalam, qira'ah, and kitabah). This orientation tends to place Arabic as a discipline or object of study that must be mastered academically. This orientation is usually synchronized with Arabic language studies at the Arabic Education Department, Arabic Language and Literature, Postgraduate programs and other scientific institutions. (3) Professional / Practical and Pragmatic Orientation is about learning Arabic for professional, practical or pragmatic interests, such as communicating orally (muhadatsah) in Arabic to become an international worker, diplomat, tourist, trade mission, or to continue studies in Arabic countries. And (4) Ideological and Economic Orientation, which is about learning Arabic to understand and use it as a medium for the interests of orientalism, capitalism, imperialism, and so on (Yahya et al., 2020). This orientation can be seen from the opening of several Arabic language course institutions in Western countries.

As an international language, Arabic has been recognized by the world. Of course, this would have a significant role in improvisation and competition at the international level. This change should be supported by aspects of language development and linguistics and the improvisation and innovation on the methodological aspects and learning techniques. This statement can certainly be proven concretely and factually in Arabic learning activities. Recently, there have been many interactive and innovative Arabic learning models and techniques that increase students' enthusiasm for learning Arabic simultaneously and continuously. This of course must be optimized by educators in the real classroom actively and creatively so that the Arabic learning process can be conducted optimally, and the learning objectives can be achieved (Asy'ari, 2019). 
The theme of teaching and learning materials in learning Arabic can also be directed to daily-informal conversations at home, school, at markets, airports, hospitals, and other public places. Learners can also be provided with Arabic language skills related to worship, such as Umrah and Hajj, which would later be useful for themselves and their families. Besides, at a higher level, Arabic learning materials can also be provided more formally, which can be taken from various types of works and contexts so that future Islamic learners can internalize Arabic learning in their daily lives (Setyawan \& Anwar, 2020).

Practically, Language Center in each Islamic Institution can design a more structured learning system by establishing several Arabic teaching and learning principles. First, establishing and developing a particular curriculum based on clear scientific standards is discussed and finalized in joint meetings and deliberations. Second, the preparation of syllabi and teaching materials based on research and other sources combined with modern technology and other media. Third, uploading syllabus and teaching materials in a database/website as the central storage and development of the evaluation process. Fourth, enrichment and development of teaching materials into adequate books or scientific works. And the last, an increase in the number of scientific papers for publication (Wahab, 2015).

\section{Modern Educational Technologies in Arabic Teaching and Learning}

The development of the technological revolution in the modern era demands a learning process that can utilize and develop technology-based media effectively and efficiently. In this case, modern Arabic learning innovations need to be optimized and tested with various updated media that continues to evolve, creating enthusiasm and desire for learners to improve further and master Arabic to study Islamic studies. The effective use of technology and learning innovations would make it easier for Islamic scholars to understand and master Arabic and Islamic studies (Setyawan \& Anwar, 2020).

One of the main technological innovations that can be used in learning Arabic is optimizing the internet and the electronic devices that support it. With the internet, access to information throughout the world is opened widely. It can be used as a material in learning Arabic, for example, digital newspapers and literature books that 
can be used as sources of Islamic studies. Learning videos provided on the internet may also be used to optimize Arabic learning and create some insights into using this language in a non-formal approach with more fun and exciting method. Arabic learning materials can also be combined with learners' soft skills and hard skills in a variety of skills as future assets for Islamic learners in the future. The combination of learning Arabic and the work skill in society it would prepare Islamic learners to prepare for a better future (Setyawan \& Anwar, 2020).

The internet is a necessity that cannot be separated from everyday life, including Arabic learning. The emergence of various apps or software in learning Arabic would lead to more exciting and practical understanding. Multiple kinds of internet products, such as e-news, e-journal, e-library, e-dictionary, e-book, and others, constitute positive innovations for education due to advances in the development of information and communication technology. These innovations are also considered to have made a massive contribution to learning Arabic, such as finding Arabic vocabularies that are currently easier and faster with e-dictionary. Even if someone wants to get information or learning references, everything is possible with the internet. Even e-books as electronic books, are now considered the main research sources. Therefore, e-Learning is a solution and an alternative to learning problems, especially learning Arabic (Iswanto, 2017). E-Learning would bring about a change in learning for a better future (transformation), especially in the 21st century, which is just the beginning of the digital era.

Arabic learning innovations can also be focused on the learning methodology used by teachers. As technology and communication continue to advance, many learning methodologies can be implemented, such as suggestopedia, quantum teaching, brainbased learning and various other interactive approach methods. Also, optimizing the variation in learning media, especially technology-based media and the internet, can provide a new alternative for students to master Arabic more optimally. For example, a YouTube video is an excellent source with a wide variety and quantity of material. With good management, it would be a useful Arabic learning material. Besides, internet media would provide a real picture and example of Arabic expressions, both informal and everyday versions. In this case, many Islamic education institutions have tried to establish many Internet-based learning platforms, such as Google classrooms or other 
features of e-learning. With these efforts to optimize technology-based Arabic learning, Islamic studies' development would automatically improve continuously (Setyawan \& Anwar, 2020).

Arabic learning media is about using videos and recorded conversations in Arabic but can be done directly face-to-face using some internet devices with native Arabic speakers. Technology and learning media combined with communication technology would provide a real learning environment so that the learning quality process may be fully optimized. The types of digital media for teaching and learning Arabic would continue to develop, starting from VCDs, DVD lyrics, which later evolved into video conferences and through website-based interactive portfolios. Also, many other onlinebased learning media can be developed and innovated to improve Arabic learning activities.

\section{CONCLUSION}

Based on the discussion above, it can be concluded that Arabic learners today are different from learners in the past who focus more on routine activities by relying on written sources. In this modern era, learners have complete access and freedom to determine the direction of learning they want and need for themselves. However, they still need to have control from a language teacher or instructor so that all learning activities can be fully well- implemented. Moreover, although modern learning media can optimize the potential of learning Arabic, the traditional use of Arabic language strategies and approaches should not be abandoned. The combination of learning with traditional approaches and modern learning would provide a good variety of learning to increase student interest and motivation in learning Arabic.

Besides, the main priority in improving the quality of Arabic learning is by optimizing modern media and technology. Since Arabic linguists and scholars are considered to have the lower capability in creating media and technology of Arabic learning than other languages, the general Arabic learning process has not yet achieved the modernity principles such as: easy, fast, precise, and useful. Therefore, Arabic Education Institutions must improve the quality and quantity of a whole Arabic teaching system and learning. In other words, Arabic language experts need to partner and 
synergize with competent human resources to develop modern Arabic education and learning technology.

\section{REFERENCES}

Abdullah, A., Sulaiman, A., \& Wan Abdullah, W. (2015). Faktor-Faktor yang Mempengaruhi Motivasi terhadap Pembelajaran Bahasa Arab. Jurnal Islam Dan Masyarakat Kontemporari. 10 (8), 82-97

Andriani, A. (2015). Urgensi Pembelajaran Bahasa Arab Dalam Pendidikan Islam. TA'ALLUM, 03(1), 39-56.

Astuti, F. (2016). Optimalisasi Penggunaan “ Maraaji' Arabiyah" dalam pendidikan Agama Islam di perguruan Tinggi. Al-Ikhtibar, 3(2), 102-112.

Astuti, W. (2016). Berbagai Strategi Pembelajaran Kosa Kata Bahasa Arab. Jurnal Komunikasi Dan Pendidikan Islam. 5 (2), 177-191.

Asy'ari, H. (2016). Keistimewaan Bahasa Arab Sebagai Bahasa Al- Qur' an. Jurnal Manajemen Pendidikan Islam (Nidhomul Haq), 1(01), 21-28.

Asy'ari, M. (2019). Metode, Sistem dan Prinsip Pembelajaran Bahasa Arab yang Inovatif. An Nabighoh: Jurnal Pendidikan Dan Pembelajaran Bahasa Arab, 20(02), 288. https://doi.org/10.32332/an-nabighoh.v20i02.1465

Azhari, A. (2015). PERAN MEDIA PENDIDIKAN DALAM MENINGKATKAN KEMAMPUAN BAHASA ARAB SISWA MADRASAH. Jurnal Ilmiah Didaktika. 16 (1), 43-60 https://doi.org/10.22373/jid.v16i1.586

Azzuhri, M. (2009). Metode dan Media Pembelajaran Bahasa Arab Berbasis Internet di Era Teknologi Informasi. Insania, 14(3), 1-13.

Baharudin, H. (2017). Strategi dan Teknik Terjemahan Novel Arab dalam Kalangan Pelajar Universiti (Arabic Novel Translation Strategies and Techniques used among University Students). GEMA Online ${ }^{\circledR}$ Journal of Language Studies. 17 (4), 225-243 https://doi.org/10.17576/gema-2017-1704-15

Fajriah. (2017). Strategi Pembelajaran Maharah Kitabah pada Tingkat Ibtidaiyah. PIONIR Jurnal Pendidikan. 6 (2), 34-56

Hizbullah, N., \& Mardiah, Z. (2015). Masalah Pengajaran Bahasa Arab di Madrasah Aliyah di Jakarta. Jurnal Al-Azhar Indonesia Seri Humaniora. 2 (3), 189-198 https://doi.org/10.36722/sh.v2i3.145

Humaidi. (2017). Problematika Pembelajaran Bahasa Arab di Sekolah Tinggi Agama Islam ( STAI ) Syaichona Moh. Cholil Bangkalan. Jurnal Pendidikan Dan Pranata Islam, 8(2), 287-300.

Husen, U. (2016). Integrasi Bahasa Arab ke Dalam Ilmu-Ilmu Keislaman pada Prodi Pendidikan Agama Islam (Pai) Ftk Uin Ar-Raniry. Lisanuna, 5(1), 87-104

Iswanto, R. (2017). Pembelajaran Bahasa Arab dengan Pemanfaatan Teknologi. 1 (2), 139-153 Arabiyatuna: Jurnal Bahasa Arab. https://doi.org/10.29240/jba.v1i2.286

Kassim, N., Damit, S. A., \& Taat, M. S. (2017). Pengaruh sikap pelajar dan pengajaran guru terhadap Penguasaan Bahasa Arab dalam kalangan pelajar PPPIB, UMS. Jurnal 'Ulwan. 1 (5) 125-142 
M. Khalilullah, S. A. M. (2011). Strategi Pembelajaran Bahasa Arab Aktif (Kemahiran Istima' dan Takallum). Jurnal Sosial BudayaKhalilullah. 8 (2), 219-235

Mahmudah, S. (2018). Media Pembelajaran Bahasa Arab. An Nabighoh Jurnal Pendidikan Dan Pembelajaran Bahasa Arab. 20 (1), 129-138. https://doi.org/10.32332/an-nabighoh.v20i01.1131

Miftah Wangsadanureja. (2017). Peran bahasa arab dalam memahami pendidikan agama islam dengan pendekatan berfikir knowledge. Jurnal Pendidikan Islam, $8(1), 33-48$.

Muradi, A. (2014). Pendekatan Komunikatif dalam Pembelajaran Bahasa Arab. Arabiyat: Jurnal Pendidikan Bahasa Arab Dan Kebahasaaraban. 1 (1), 29-48. https://doi.org/10.15408/a.v1i1.1129

Pane, A. (2018). Urgensi Bahasa Arab; Bahasa Arab sebagai Alat Komunikasi Agama Islam. Komunikologi, 2(1), 77-88.

Sagala, R. S. (2016). Faktor-Faktor Penyebab Rendahnya Aktivitas Belajar Bahasa Arab Peserta Didik Kelas VII Di MTs Nurul Falah Bukit Kemuning. Jurnal Al Bayan, Jurnal Jurusan Pendidikan Bahasa Arab. $8 \quad$ (2) 1-18 https://doi.org/10.24042/albayan.v8i2.364

Sangid, A., \& Muhib, M. (2019). Strategi Pembelajaran Muhadatsah. Tarling : Journal of Language Education. 2 (1), 1-22.https://doi.org/10.24090/tarling.v2i1.2226

Satrio. (2018). Urgensi Penguasaan Bahasa Arab dalam Studi Islam di Indonesia. Perada: Jurnal Studi Islam Kawasan Melayu, 1(2), 163-177.

Setyawan, C. E., \& Anwar, K. (2020). Peran Bahasa Arab Dalam Pendidikan Islam Sebagai Urgensitas Mengahadapi Revolusi Industri 4.0. Lahjah Arabiyah, 1(1), $14-29$.

Shodiq, M. J. (2018). Pembelajaran Bahasa Arab Aktif-Inovatif Berbasis Multiple Intelligences. Al Mahāra: Jurnal Pendidikan Bahasa Arab. 4 (1), 125-148. https://doi.org/10.14421/almahara.2018-041-07

Supriyadi, S. (2017). Community of Practitioners: Solusi Alternatif Berbagi Pengetahuan antar Pustakawan. Lentera Pustaka: Jurnal Kajian Ilmu $\begin{array}{llll}\text { Perpustakaan, Informasi Dan } & \text { Kearsipan, }\end{array}$ https://doi.org/10.14710/lenpust.v2i2.13476

Ummi, H. U., \& Mulyaningsih, I. (2016). Penerapan Teori Konstruktivistik Pada Pembelajaran Bahasa Arab di IAIN Syekh Nurjati Cirebon. Indonesian Language Education and Literature. 1 (2), 42-52

Wahab, M. A. (2015). Pembelajaran Bahasa Arab Di Era Posmetode. Arabiyat, 2(1), 59-74.

Wahab, O. L. A. (2013). Motivasi Belajar Bahasa Arab Mahasiswa Stain Kendari (Analisis Problem dan Solusinya) Dosen Bahasa Arab STAIN Sultan Qaimuddin Kendari. Al-Ta'dib, 6 (1), 71-88

Wahyuni, I. (2017). Bahasa Arab Dalam Konteks Simbol Agama (Analisis Terhadap Tujuan Pembelajaran pada Perguruan Tinggi Islam). Zawiyah, 3(2), 78-92.

Wekke, I. S. (2016). Lingkungan Belajar Bahasa Arab dan Konstruksi Karakter Santri: Tinjauan Pesantren Minoritas Muslim. Al-Lisan. 1 (2), 1-27

Wijaya, M. (2017). Manajemen Pembelajaran Bahasa Arab Sinergi Teori Dan Praktek Manajemen Pembelajaran Bahasa Arab Sinergi Teori Dan Praktek. Al-Tanzim, 1(1), 1-18. 
Heni Verawati \& Uswatun Hasanah

Available Online at https://journal.iaingorontalo.ac.id/index.php/al

Yahya. Y.K, Mahmudah. U, Muhyiddin.L. (2020) De-sakralisasi dalam Pembelajaran Bahasa Arab di Indonesia: Analisis Bahasa sebagai Identitas Agama. Jurnal Lingua Applicata, 3 (2) 57-70 